\title{
Discipline as a Factor in Academic Performance in Kenya
}

\author{
Philomena Mukami Njoroge \\ Mount Kenya University, School of Education \\ Ann Nduku Nyabuto \\ Mount Kenya University, School of Education
}

Doi:10.5901/jesr.2014.v4n1p289

\begin{abstract}
Discipline is a vital ingredient for the success of students' academic performance. The Government of Kenya through the Ministry of Education (MOE) has always set up commissions of enquiries anytime the secondary schools unrests become a great concern, especially when it leads to massive destruction of property and death of students. The MOE has always wanted to get to the bottom of the matter and establish ways in which discipline can be enhanced. However, discipline in public day secondary schools has deteriorated in the past few years, especially since the ban of the cane jeopardizing the national goals of economic and industrial development (MOE 2008). In spite of efforts by the schools, indiscipline is the order of the day and it may be assumed that it hampers good academic performance. The Teachers Service Commission (TSC) has further ensured that each school has a teacher-counselor to strengthen discipline yet many schools particularly in Ruiru District have continued to find it difficult to establish a strong culture of good discipline. The academic performance in Ruiru District has continued to deteriorate. The schools have also been experiencing students' indiscipline. Although there are many factors that affect the academic performance, the factor of indiscipline has not been conclusively looked in to. It was therefore important and urgent to have an in-depth assessment of the role of discipline on academic performance in order to solve the problem. In view of the above, the task of this paper is to assess the causes of indiscipline, ascertain the relationship between students' discipline and academic performance, find out challenges faced by teachers in dealing with students' indiscipline and develop strategies for improving discipline in public day secondary schools in Ruiru district, Kiambu County in Kenya.
\end{abstract}

Keywords: Education, Discipline, Schools, Learning, Behavior

\section{Introduction}

Griffin (1994) points that the paramount aim of school discipline should be to endow each learner with habits such as self respect and proper pride in his own integrity that he will observe the norms of good conduct when not under compulsion or supervision and will carry them eventually into adult life. Sound discipline is an essential ingredient in the creation of a happy and industrious school community. Learners learn to the best of their abilities in an orderly and safe environment. The environment should not be intimidating and threatening to the learner. Mothata and Squelch (1997) state that if discipline is not taken into consideration, the school environment will be dangerous and the educational process may be disrupted. This may also affect the educational performance of the learners and the overall educational attainment. Similarly Levin and Nalon (1991) state that, in addition to the obvious impact on the teaching and learning environment, disruptive behaviour can also affect the learners' safety, readiness to learn as well as future behavior. In the opinion of Hill (1994) ill-discipline can destroy the possibility of a safe and orderly environment and thereby hamper the core purpose of the school. It is therefore necessary that discipline is maintained in a school for the welfare and safety of learners and educators and for the success of the educational process.

Lack of learner discipline in many public schools throughout the world has been a matter of great concern for school management and educators and to a lesser extent for learners themselves, parents and the general public (Wayson \& Pinnell, 1994). Charles (1996) notes that numerous studies that were conducted by researchers in the United States of America in 1992, have listed unrests as a major problem with which educators must contend. Lack of discipline and safety in schools has been one of the challenges facing Kenyan schools during the past number of years. Despite the commitment of the government to provide resources and improve school conditions, and minimize school strikes, cases of students' indiscipline continue to be a major problem in the learning institutions and have hampered the education progress of affected learning institution. Students' indiscipline is manifested in various ways and takes different 
form in various schools such as commotions, disturbances, class boycotts, neglecting to do assignments, mass indiscipline, riots and violent strikes that may lead to rape, death, and destruction of school property. This not only affects the students' performance but also scare others who develop phobia for boarding schools.

Discipline at school plays a vital role in the achievement of expectations and goals. It also plays a vital role in the acquisition of sense of responsibility in learners as well as educators. Educator's ability to exercise effective discipline as suggested by Dunham (1984) is essential. Good discipline creates a good image of the school and prepares learners for the future. Disruptive behaviour amongst learners is eliminated if there is good discipline at school. The implementation of effective discipline at school is a key for the learner in his journey to adulthood. It is believed that students' indiscipline worsened due to a number of factors including the quality of school administration, students living conditions and poor academic performance which prominently featured in the Task Force Report (MOE, 2001). Indiscipline in schools, and consequently, school strikes, destroy the teaching- learning environment. However, the Ministry of Education and stakeholders would like schools to establish and sustain a peaceful atmosphere in order to ensure school effectiveness, hence the achievement of school objectives. In spite of the Kenya Government effort to ensure quality education and effective management of schools, there are emerging challenges in the state of students' discipline (MOE, 2001; Sisungo, 2002). Academic performance in national examinations in central province has been below average with schools in Kiambu County performing dismally. Below is KCSE 2010 performance by Mean Standard Score categories showing Performance of schools by Counties in Central Province.

Table 1.1: KCSE 2010 Central Province Performance by MSS Categories showing the Distribution of Schools by Counties

\begin{tabular}{|c|c|c|c|c|c|}
\hline \multicolumn{5}{|c|}{ Categories of Mean Standard Score per County Schools } & \\
\hline County & $1.00-2.99$ & $3.00-5.99$ & $6.00-8.99$ & $9.00-12.00$ & Total Schools \\
\hline Kiambu & 60 & 179 & 39 & 02 & 280 \\
\hline Murang'a & 30 & 203 & 26 & 01 & 260 \\
\hline Nyandarua & 14 & 101 & 17 & 03 & 135 \\
\hline Nyeri & 32 & 129 & 27 & 03 & 191 \\
\hline Kirinyaga & 07 & 87 & 14 & 01 & 109 \\
\hline National & 0 & 0 & 0 & 06 & 6 \\
\hline Total & 143 & 699 & 123 & 16 & 981 \\
\hline$\%$ & 14.577 & 71.254 & 12.538 & 1.631 & 100 \\
\hline
\end{tabular}

Category $1.00-2.99$ - Mean grades between $E$ and $D$ which stand for very poor performance.

Category 3.00 - 5.99 - Mean grades between $D$ and $C$ which stand for below average performance.

Category $6.00-8.99$ - Mean grades between C and B which shows average performance.

Category 6.00 - 12.00 - Mean grades between B and A which stands for very good performance.

\section{Source: Central Province KCSE 2010 Examination Results Analysis}

As indicated in Table 1.1 above majority of the secondary schools are in the 3.00-5.99 category which translates to $71.254 \%$ of the total schools and $14.577 \%$ of the schools ranging in the $1.00-2.99$ category. This is an indication that academic performance in most schools in the province is alarming with high wastage grades. This could be attributed to indiscipline experienced in the schools.

Kiambu County had majority of schools, 60 in the 1.00-2.99 category. Only 40 schools out of the 280 had scored above a MSS of 6.00 . This is an indication that academic performance in the county is poor. Discipline which is paramount to academic performance must be looked into for the achievement of school and students goals.. Docking (1996) views discipline as a significant aspect in establishing an orderly system that creates the condition in which learning takes place and that allows the aims and objectives of the school to be achieved.

Ruiru district has continued to experience student indiscipline in public day secondary schools and this may be a major contributing factor to poor academic performance in the national examinations as indicated in figure 1.2 below;

Table 1.2: Ruiru District KCSE Performances in Public Secondary Schools

\begin{tabular}{|c|c|c|c|c|}
\hline Year & 2008 & 2009 & 2010 & 2011 \\
\hline Mean score & 4.013 & 4.157 & 4.134 & 4.154 \\
\hline Meangrade & $\mathrm{D}+$ & $\mathrm{D}+$ & $\mathrm{D}+$ & $\mathrm{D}+$ \\
\hline
\end{tabular}

Source: Ruiru District KCSE analysis 
As indicated in Figure 1.2 above the KCSE performance in Ruiru District is below; average with little improvement throughout the four year period. This problem needs to be addressed to alleviate the situation. Few studies have suggested an assessment into how the students' discipline affects the academic performance in public day secondary schools. Therefore this paper assesses the role of discipline on academic performance in public day secondary schools in Ruiru district, Kiambu County.

\section{Theoretical Bases}

This paper is based on production theory as revealed by Psachalopoulos and Woodhall (1985). Production theory models the behavior of a firm as an open system that makes decision on what quantities and resources to use to produce particular quantities (Monk, 1990). The Production model has three parts namely inputs, process and outputs produced when the inputs are molded during processing. The process of converting the inputs into desired output is affected by external factors present in the environment where they are drawn from and internal factors within the firm during processing. In theory if all the factors were to be held constant, the outputs of the firm would be $100 \%$; all the inputs will be converted into the desired products. However, due to the external factors where inputs were drawn from and the internal factors during processing, the number of outputs will fall below $100 \%$ depending on the intensity of the factors. A school is an open system like a firm. The inputs are the students. The process of transforming the students to produce outputs is required; these include teaching, guidance and counseling, modeling, molding, and mentoring. Outputs would be the number of students who successfully complete their studies and perform well and increase transitional rates to the next level. Processing of inputs into outputs is affected by various factors resulting to internal inefficiency in terms of suspension, repetition and drop out.

Inefficiency reduces the number of students who successfully complete the course and those who attain a good grade hence reducing the quantity of output to below $100 \%$. For example, a badly behaved student may be suspended and due to suspension, he or she may perform poorly academically. This is likely to lead to repetition, which may psychologically make the student lose interest in his or her studies and eventually lead to poor academic performance. External factors such as excessive control at home may create discipline problems in school. The conflict between the children's desire for freedom and parent's unwillingness to allow it may actually encourage them to rebel and the rebellion may be extended to school. Rebellion at school may lead to lack of self efficacy which hampers academic achievement. Conducive school environment where effective teaching and learning takes place, and learners needs well taken care of will lead to good academic achievement. This is determined by the availability of resources, relevant teaching style, guidance and counseling, modeling, teacher efficacy and reward and punishment.

\section{Overview of students' Indiscipline on Academic Performance}

Ovell (2001) noted that discipline in schools is essential for effective learning, good teacher relationship and peer adjustment. A democratic form of discipline leads to a healthy classroom environment that in turn promotes respect for education and a desire for knowledge. Reports on the problem of indiscipline and unrests in schools have been a common feature in the media for a long time. For instance Muchemi ( 2001) in his article 'Students face life in prison over strikes' gave a chronological account of protests and destruction in public schools. The issue of unrests and indiscipline in schools is of great concern and it has become a worrying trend in that it has evolved from simple protests to the destruction of property and burning of prefects. The upshot is that student disturbance is negatively affecting academic performance. The report prepared by the Provincial Education Board (Central Province) indicated that indiscipline was rampant, not only in Central province but in the whole country.

Lewis and Doorlay (2006) emphasize that if the educators themselves are well disciplined and understand their work as well as their learners and possible challenges, there could be only good results in academic achievement. They further asserted that if educators are exemplary and know their work and understand the learners, then the learners will be in a good position to achieve academically. Sonn, Fisher and Bustello(1998) stress the fact of self respect and respect to others. If self respect prevails in the school situation, learners will learn self discipline. If there is self discipline, there are more chances of having direction in the fulfillment of the learners' goal so positive academic achievement is possible which translates to good academic performance. If the school has good facilities and the needs of the learners are well catered for, there will be good academic achievement. This can also be improved by the availability of resources, relevant educators, enough learning space which is conducive to learning, relevant teaching style and clear code of conduct. 
Williams (1982) stated that discipline involves all stakeholders, programmes as well as personality and school climate. Charlton and David (1993) assert that if there is no proper family environment social differences and learners are from disadvantaged social areas; this could lead to bad discipline and negative results academically. However, if the family background is not good, different social classes are present in the school, school is located in a socially disadvantaged area and there is bad influence of peer groups it will have a negative effect on discipline so academic achievement will also be negatively affected. Discipline is essential particularly during the early years in both primary and secondary schools. It is not only the key to good academic performance, which all parents, students and teachers cherish and aspire but also a preparation for success throughout life. In fact, it has been observed that good academic qualifications without good foundation of self-discipline, the individual is useless to him/herself, family and the society. Every school is expected to have a standard code of conduct which every student is supposed to adhere to willingly without compulsion. The schools also need to provide the vital support services through guidance and counseling in order to instill in students a sense of responsibility and curb incidences of ugly and destabilizing student's indiscipline in schools.

Where there is disobedience, it is expected that the necessary disciplinary measures will be taken according to the laid-down regulations in education act. School discipline is a powerful emotive subject since it is one of the main determinants of students' success in their academic work, and it is an issue that has generated public concern (MOE, 2001). Most people equate falling academic standards in schools to low standards of students' discipline (Griffin, 1994). It is on this basis that the role of the head teachers and teachers within the school's administrative and instructional services becomes crucial. In this reference, students' discipline precedes quality education and with the increased violence, drug abuse and crime in the Kenyan society, stability in schools is threatened. This is a worrying factor among most stakeholders.

\section{Causes of Indiscipline in Schools}

Various views have been given regarding the cause of indiscipline. According to Okumbe (1985) indiscipline has causes that exist in the school, in the society and in the psychological states of the students. Some of the factors contributing to indiscipline include:

\subsection{Family and Parenting Issues}

According to Robertson (1999), some children at schools can be disruptive because 'they have been subject to distorted or inadequate care throughout childhood due to a variety of family and economic difficulties'. It is because of that neglect that they are now demanding attention in the classroom. In addition, he says that school failure and behaviour problems that may have their origin on home background are strongly associated. When children with similar problems are not doing well in their learning areas or subjects, they have a tendency to disrupt the attentive and concentrating learners.

McGuiness (1994) supports the view of the family conditions as either a positive or negative contributor to learner behaviour. Accordingly, he says that the individual child's family, too, can seep negatively and, of course, positively into the classroom. He argues that children coming from homes with no tradition of valuing education often develop learning problems. He says that such a child mostly fails to see the value or importance of education and this negatively influences the child's interest towards education. Jones and Jones (1995) write about some social factors in the life of a child that may positively or negatively influence his/her behaviour. They mention family break-ups, poverty, stressful lives and substance abuse. These negatively affect the overall social wellbeing of the student and therefore affect the discipline outcomes at home and in school. The resultant indiscipline cases in schools disrupt the learning process leading to time wastage for the student causing it and the other innocent students as well.

\subsection{Societal Influence}

The dawn of twenty first millennium saw an increasing number of strikes and excessive anti- social behaviour in Kenyan schools (MOE, 2001). The period between 1990 and 2002 was characterized by students riots in secondary schools and in some cases this led to massive loss of lives valuable school time, and damage of schools scarce physical facilities (Republic of Kenya, 2002) Stangham (1989) notes that the modern society is becoming more indiscipline, with enhanced lawlessness, violence and permissiveness.

Furthermore, Mutie (1999) asserts that indiscipline is a cancer in many schools and can be attributed to negative 
internal and external influences, which cause students to lack a sense of direction and a sense of purpose. According to him what has been given to teenagers is immorality, pornography, violence and more violence. The children will replicate what have been given to them. The strikes and indiscipline experienced in schools are therefore a reflection of our society. Similarly Okumbe (1985) says that the students are exposed to models in the society. They read thrilling stories, watch violence on television and even in real life situations. There are so many indiscipline acts that students are imitating and therefore they have learnt from the society around them. Some of the aspects which impact upon schools negatively include the use of drug and alcohol, rudeness, unacceptable verbal expression of dissatisfaction, bullying fellow students, boycott of lessons, assaults and indecent behaviour (MOE, 2001)

\subsection{School Environment}

Obediant (1997) notes that under qualified teachers in overcrowded classes can lead to violence in schools. The author also writes of teachers' use of fixed and predetermined curriculum as a particular source of classroom violence. Jones and Jones (2006) advocated for interdependence of management and instruction (teaching) functions in classrooms and in school at large. Schools without planning, or not ready for classroom activities and management, which has to do with controlling students' behaviour give learners a chance to misbehave and may find difficulty in responding to disruptive behaviour. The response to disruptive behaviour may be worse where there are no firm and fair codes of conduct that are enforced consistently.

Authors such as Fontana (1985) draw our attention to the causes of bad behaviour. One of the causes of bad behaviour is the children's need for status and prestige in the eyes of the class. As children grow up, this need for status and prestige grows and it means that they want to be thought of well by their friends. It is at this stage of growth that children also try to establish their own identities. In the process they become hostile and aggressive towards their teachers and usually want to be supported by the whole class. He goes on to say that children always criticize adult behaviour. Children always look up at teachers as people who cannot fulfill learner demands. They look upon teachers as failures who cannot fulfill the children's expectations. He argues that all these factors contribute to behaviour problems in the class. Rwamba (2000) argued that lack of democratic leadership together with communication breakdown is a major cause of indiscipline in schools. He suggested that there is a relationship between learning and indiscipline. Cognitive skills are crucial in terms of academic success, self-esteem, coping skills and overall resilience. In the absence of discipline, the learning and teaching process are hindered. Time is wasted and energy is misdirected to deal with issues emanating from unrest. The prefects also need to be trained in the way to handle issues. Unfortunately, they do not undergo any training, they are only appointed and expected to perform duties without being given the directions to follow.

Kenyan secondary education system is heavily overloaded with academic stuff and since the level of achievement is not the same, this could be a reason for frustration resulting to indiscipline. According to MOE (2001) some students who may not be fully focused on academics, view school as waste of time. Jones and Jones (2006) say schools have not fully adapted to students' non academic needs. Teachers tend to be examination oriented hence implementation of the curriculum does not cater for holistic development of the student. The curriculum is still overloaded despite the current reduction to the number of examinable subjects.

\subsection{Negative Peer Pressure}

Cowley (2001) understands that peer pressure among learners is a strong factor in the disruptive behaviour of learners. In the classroom the learner who can manage to make the whole class laugh at the teacher gains a great deal of status within the group. Rogers (2000) agrees with Cowley about peer pressure and its influence in child behaviour. He draws our attention to attention seeking behaviour which sometimes is accompanied by inappropriate or bad language or swearing. Peer pressure, drugs, breakdown of family and social values and hopelessness contribute greatly to indiscipline in schools. Anti-social behaviour of school children can also manifest itself outside the classroom - on the playing field for instance. Authors and researchers (Walker, Colvin \& Ramsay, 1995) argue that children need to overcome any problems of adjusting to good, acceptable and tolerable behaviour in order to be accepted by teachers and their peers. The failure to adjust and be accepted by other learners can go a long way in causing and worsening bad behaviour in children. 


\section{Relationship between Indiscipline and Academic Performance}

The problem of indiscipline in schools is not unique to Kenya. It is a global issue of great concern, spanning political, economic, geographical, racial and even gender boundaries. There is a growing concern regarding indiscipline in schools within the United Arab Emirates (Vockell, 1991), where teaching methods were blamed for the children's indiscipline. The parents were getting anxious and frustrated as they complained of the rising incidents of indiscipline and violence in schools. The concern was not only on the risk of destruction of property and injury to persons but also the poor academic performance associated with the growing trend of indiscipline.

Mumo (2004) in her research study on student unrests and indiscipline reported that discipline is considered vital for students' academic and social success. A good academic qualification without a good foundation of discipline of the individuals is of no use to the individuals, their families and the society. The society invests heavily in the education of its citizens. A positive correlation between discipline and academic performance was found in this study showing that students that are well disciplined perform well academically.

According to the Akala (2002), students and teachers in schools affected by unrest find it difficult to restore working relationship after the unrest. The emotional and psychological trauma that characterizes the aftermath of students' unrest strains further interaction amongst the people. The issue of emotional and psychological impact due to unrests in schools has not featured in various reports discussed so far. Akala suggested that there would be need for training of teachers in conflict management as opposed to use of force, which brings anger and resentment.

Indiscipline in schools has affected the learner's academic performance and their progress in school. Wayson and Pinnell (1994) states that good discipline helps to develop desirable student behavior. If a school has effective discipline, the academic performance will be good. Directions on the side of the learners as well as educators will be easy and smooth. Gawe, Vakalisa and Jacobs (2001) emphasize co-operative learning as a solution. If a school lacks effective discipline, the achievement academically will be poor.

There is a growing concern that many schools are at risk of becoming unsafe for teaching and learning. For this reason, head teachers and teachers have an awesome responsibility of, not only teaching effectively to ensure that students achieve academic excellence, but also have the task of imparting and ensuring the necessary discipline for the youth to grow as responsible citizens (Griffin, 1994). In this case the youth should make meaningful contributions toward the development of their country, as a result of their going through an education system with good discipline. In this regard, secondary schools personnel management, policies, structures, aims and objectives; should be geared toward the provision of a sound learning environment since schools personnel are stakeholders' agents for instilling discipline.

Vockell (1991) emphasizes that a school environment and students' home background factors contribute to making the school an effective atmosphere for the development and control of learners' behaviours. However, if these have negative effects, the students and generally the school become chaotic and more of a trouble spot rather than a center for learning.

\section{Challenges in Dealing with Indiscipline}

There has also been a variety of reactions to the rising incidences of indiscipline and unrests in schools. Various views have been expressed regarding the cause of the indiscipline and possible solutions to the problems have been proposed. The 'rod' was banned in Kenya as a means of disciplining students in school according to Wachira (2004). This ban has been blamed for the increase in indiscipline, and naturally, there have been calls to rethink the decision. However, these views are not in agreement with organizations such as the Kenya Human Rights Commission (KHRC). Subsequently, the reintroduction of caning was ruled out (Wachira ,2004).

Kanja (2008) states that, teachers have taken a back seat in discipline as there have been cases of teachers being dragged to court for punishing students which have prompted many to take a back seat over students behavior. When teachers, prefects and peer mentors lack the backing of the school administration, they cannot succeed in enhancing discipline and decent behaviour effectively. Further, it raises the issues about the challenges facing head teachers in dealing with discipline which this study wishes to pursue so as to avail proactive strategies to avert such maladaptive behaviour and situations that are likely to precipitate similar vices in learning institutions.

The big numbers of learners that teachers have to deal with in one classroom are a daunting and intimidating prospect (Fontana, 1985). People who take interest in the education of children are aware of this problem. Teachers agree that once the class size rises above 35 , it is impossible to maintain discipline, or even an acceptable low noise in the classroom (Wachira, 2004). 
Jones and Jones (2006) note that schools have not adapted to students` non academic needs. Teachers tend to be examination oriented hence the curriculum does not cater for the holistic development of the student. High expectation in performance of national examinations causes teachers to be pre-occupied with testing at the expense of character development.

\section{Possible Strategies for Improving Discipline in Schools}

Different approaches can be used to deal with indiscipline cases in the secondary schools. These involve the parents, teachers the school administration and the pupils themselves.

\subsection{Classroom Control and Management}

Disruptive pupils in the classroom have long been a problem (Fontana, 1994). Fontana writes about classroom control and strategies for guiding and reshaping problem behaviors. He refers to attempts made in the USA and in the UK to improve behaviour. The suggestion of a behaviour modification approach takes it's starting point from the recognition that the behaviour which is acceptable tends to be rewarded while those types of behaviour that receive no reward tend to be eliminated. Fontana (1994) writes about the cognitive approach to the problem of disruptive behaviour. The cognitive approach deals with the question of motivation, interest and life goals. If levels of motivation and interest are high, then learning takes place more readily. Although individuals may vary, in most cases where children are allowed or given chance to manage themselves by, for example, choosing own leaders to monitor noise levels and task completion, they will behave better.

Alexander and Carla (1995) believe that small classes have a positive effect on student behaviour. In addition to small classes, the above-mentioned authors also recommend that schools that are smaller and whose curriculum is easy to adjust may contain programmes aimed at changing perpetrators or aimed at prevention of ill-discipline. Such programmes may be those that can promote social and cognitive skills in learners and are easily applied.

Chaplain (2003) observes that the goal pursued with rules for the classroom and the whole school leads to a safe environment and good working relationship. Rules should be clear, achievable and be subject to the school policy and government regulations. Rules can be for prevention and also, after the act of misbehaving, prescribe the consequences of the offence in relation to its seriousness. Chaplain further says that the rules in schools are mostly rules that relate to teacher-student and student-student relationships. The code of conduct of a school can maintain or improve an existing positive learning situation. It can, if rules and regulations included are enforced by school authorities and complied with by learners, reduce the task of using tough disciplinary actions or measures against misbehaving learners.

\subsection{Behaviour Control}

Charlton \& David (1993) argue that a behavioral approach assumes that, if problem behaviour occurs because of particular antecedents and consequences, it can be made to occur less by changing those conditions. They also suggest that disruptive behaviour can be reduced through good pastoral care planning together with more discussion and less shouting. Wilson (1974) writes that discipline is meant to impose external standards and control on individual conduct. He goes on to say that reward and punishment are techniques of control. He also notes that employment of these techniques of behaviour control is part of the teacher's responsibility for maintaining discipline in the classroom.

\subsection{Role Modeling}

Vockell (1991) is of the opinion that generally parents and teachers should reinforce behaviours that are compatible with any desirable behaviours in children through being exemplary. Roffey \& O'Reirdan (2003) refer to behaviour that is consistent with what students expect from adults. Normally, students or children expect from adults a type of behaviour that is characterized by good manners and a helping hand to others. Wolfgang (1999) agrees that a teacher should at all times be exemplary in being responsible and committed to people around him or her. The above is based on the fact that learners or children in general, worship their heroes and imitate those whom they appreciate and admire. A teacher who approaches his class with honesty, trustworthiness and being exemplary will in turn be received with warmth and eagerness by learners. In such situations learners will not be rebellious (Charles \& Charles, 2004). 


\subsection{Preventive Control Techniques}

Smith \& Misra (1992) suggest use of antecedent control techniques. These strategies are mainly for the prevention of bad behaviour and should include activities that eliminate boredom and frustration in the classroom. Rules and seating arrangements accompanied by promotion of good relationships amongst learners are also suggested here. Evertson, Emmer and Worsham (2003) support the idea and say that preventive measures are more important than reactive measures. Algozzine and Kay (2002) agree with the above mentioned idea and even suggest productive academic instruction i.e. a programme during teaching that will aim to prevent bad behaviour in learners.

Feshback (1983), in her approach to the disruptive aggressive child, suggests the promotion of empathy among children and control of aggression through empathy. She defines empathy as the ability to assume the perspective and role of another person and the ability to respond effectively. She says that empathy improves behaviors that are incompatible with aggression. An emotional empathetic response can act as an inhibitor of learner individuals' aggressive words and action. However, the same author warns that empathy cannot be an overall solution for all classroom problems. Charles \& Charles (2004) write about a sense of community where every member of a class is concerned about each member of the class.

According to Weinstein \& Mignano (1993), verbal and non-verbal interventions can be used when dealing with minor misbehaviour. Verbal interventions can include giving commands softly, calling the inattentive students' name or calling the same to participate in the lesson. Non-verbal interventions such as signals, eye contact, facial expressions and proximity control allow the teacher to warn the misbehaving learner without interrupting his or her lesson.

\subsection{Detention and Withdrawal of Privileges}

According to Dadisman, King, Manahan, and Quade, (1990), after-school detention and revocation of privileges like recess approaches are more enlightened and constructive than beating learners. These authors share Mercure's (1995) ideas with respect to in-school isolation. This approach suggests that learners involved in bad behaviour should be removed from other learners and be asked to do their class work or assignments in isolated classrooms or halls. They also agree that these are meant to be constructively punitive rather than creating playtime during isolation. Evertson, Emmer and Warsham (2003) write about withholding a privilege in order to lessen unproductive social behaviour. The privilege can be any popular or desired activity and it could be restored provided an appropriate behaviour has been displayed again.

\subsection{Alternative School Reform Programmes}

Eggleton (2001) says that effective instruction, accompanied by wide effective classroom management strategies and alternative school programmes that aim to discipline for reform, should form the disciplinary approach in schools. Disciplinary strategies for reform may include guidance and counseling and remedial assistance. He also suggests a school-wide discipline policy supported by teamwork (educators) and a 'visible principal', that is a principal who is present when disciplinary problems need to be attended to, without always delegating disciplinary responsibilities to the Head of department or Deputy Principal. Evertson, Emmer and Warsham (2003) suggest as an alternative to corporal punishment educators should help each learner to realize that his/her behaviour is not acceptable and can be transformed. They suggest teachers should not attribute all the bad behaviour to the child's choice. Unwanted behaviour may have been enforced on him or her. Teachers should not always assume that the learner is the one who cannot make good choices of behaviour. Docking (1996) says that praising good behaviour in the classroom maintains appropriate behaviour and reduces behaviour problems. He warns against criticizing bad behaviour while ignoring good behaviour. Wragg (2001) supports the idea of praising good behaviour by suggesting that a teacher needs to promote good behaviour by a reward or recognition e.g. praise

Weinstein \& Mignano (1993) write about systematic behaviour modification. Such approach, they claim, needs to be paired with the teachers' attention to desired behaviour. Docking (1996) further argues that reprimanding quickly spells out how far an unacceptable behaviour can be tolerated. However, it may also raise the public status of the wrongdoer or the unwanted behaviour. Reprimanding is often accompanied by outbursts of anger from the teacher. It can therefore make relations to worsen and the situation to deteriorate to shouting and criticizing.

Smith \& Laslett (1995) say that humor can be used as an alternative to harsh punishment that can increase tension in the classroom. This can be very effective, especially if it redirects the focus away from the disruptive learner. 
Humour helps to defuse tension from a class which wants to see the teachers' reaction where the disruptive learners' behaviour aims to satisfy the 'class feelings'. A relevant joke or comment that will refer to the awkward side of the situation is suggested. Weinstein \& Mignano (1993) suggest the use of humour which, if used well, can gently remind children to mend their ways. It can also be a way of showing your learners that you can also understand the funny side of classroom life. Moreover, it shows them that you are still in control of the situation.

\section{Data Analysis, Presentation and Interpretation}

The findings have been presented thematically with the themes developed from the research questions and presented using qualitative data on tables and bar graphs. The themes are the possible causes of students' indiscipline, the relationship between students discipline and their academic performance, the challenges facing teachers in public day secondary schools in dealing with students' discipline and the possible strategies for improving discipline in order to improve academic performance in public day secondary schools.

\subsection{Response Rate}

The study administered the research instruments to the subjects and the response rate is shown by the data on Table 4.1

Table 4.1: Response Rate

\begin{tabular}{|l|c|c|c|c|c|}
\hline \multicolumn{1}{|c|}{ Instrument Category } & \multicolumn{2}{|c|}{ Response } & \multicolumn{2}{c|}{ Non Response } & \\
\hline & Frequency & $\%$ & Frequency & $\%$ & Total \\
\hline Questionnaires & 126 & 100 & 0 & 0 & 100 \\
\hline Interview & 6 & 100 & 0 & 0 & 100 \\
\hline \multicolumn{1}{|c|}{ Total } & 132 & & 0 & & \\
\hline
\end{tabular}

Source: Author's calculations

Data on Table 4.1 indicates that the research was successful in that 126(100\%) of the respondents returned the questionnaire and therefore $100 \%$ was a good response and quite representative. The data further reveals that 132 (100\%) respondents participated.

\subsection{Description of the Population}

The study involved one hundred and thirty two subjects that comprised principals, dean of studies, form two and three students in Ruiru District. Schools involved in the study were public day secondary schools. Further, schools were categorized as mixed, girls and boys schools.

\subsection{Demographic Data of Respondents}

The demographic profile provides information about the population structure, and helps to create a mental picture of the subgroups that exist in the overall population. Demographic information from the study subjects was obtained to understand the sample characteristics and to determine if samples are representative of the populations of interest (Kirton, 2000). Although demographic variables cannot be manipulated, the study can explain relationships between them and dependent variables. The study investigated the respondents' characteristics by establishing their gender, age, academic qualification and experience.

\subsection{Gender}

The study sought to establish how the sample population was distributed by gender, and enable cross tabulation of response in this light. Table 4.2 data reveals how the study subjects were distributed by gender. 
Table 4.2: Gender Distribution of Respondents

\begin{tabular}{|l|c|c|c|c|c|}
\hline \multicolumn{1}{|c|}{ Category of Respondent } & \multicolumn{2}{|c|}{ Male } & \multicolumn{2}{c|}{ Female } & Total \\
\hline & $\mathrm{F}$ & $\%$ & $\mathrm{~F}$ & $\%$ & \\
\hline Principals & 2 & 33.3 & 4 & 66.7 & $100 \%$ \\
\hline Dean of studies & 2 & 33.3 & 4 & 66.7 & $100 \%$ \\
\hline Students Total & 72 & 60 & 48 & 40 & $100 \%$ \\
\hline \multicolumn{2}{|c|}{76} & & 56 & & 132 \\
\hline
\end{tabular}

Source: Author's calculations 2012

According to the data shown on Table 4.2, majority (66.7\%) principals were female while $33.3 \%$ were male. The data further shows that $33.3 \%$ dean of studies were male as compared to $66.7 \%$ females. The data also indicates that majority (60\%) students' respondents were boys as compared to $40 \%$ girls. The overall gender of the population indicates that $58 \%$ of the respondents were male while $42 \%$ were female. It can therefore be concluded from the findings that gender was fairly distributed in the sample population. The above data is shown on the bar graph below;

Figure 4.1. Distribution of Respondents by Gender

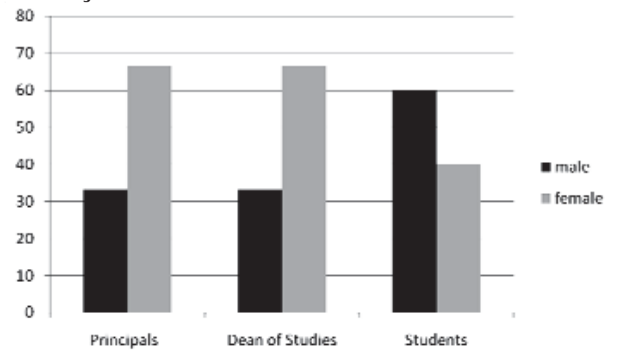

\subsection{Age}

The study sought to establish age of students. Data on Table 4.3 presents information pertaining student age.

Table 4.3: Age Distribution of Students

\begin{tabular}{|l|c|c|}
\hline \multicolumn{1}{|c|}{ Age Interval } & Frequency & Percentage \\
\hline 14 years & 4 & 3.3 \\
\hline 15 years & 7 & 5.8 \\
\hline 16 years & 45 & 37.5 \\
\hline 17 years & 62 & 51.7 \\
\hline 18 years and above & 2 & 1.7 \\
\hline \multicolumn{1}{|c|}{ Total } & 120 & 100 \\
\hline
\end{tabular}

Source: Author 2012

Data shown on Table 4.3 indicates that majority (51.7\%) of the students were aged 17 years while the minority were aged 18 years and above. a bar graph illustrating the information is shown below.

Figure 4.2. Age Distribution of Students

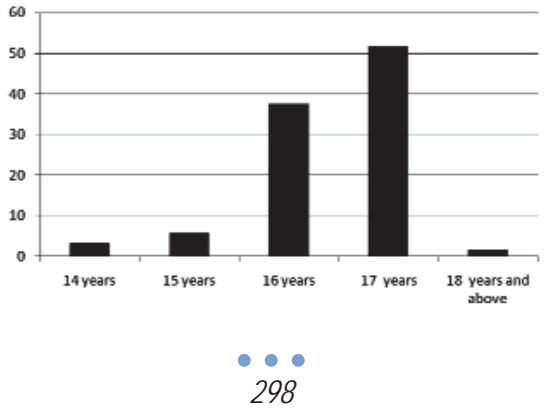




\subsection{Academic Qualification of Dean of Studies}

The study sought to establish the academic qualifications of dean of studies and the results are elicited in the table 4.4 below;

Table 4.4: Academic Qualification of the Dean of Studies

\begin{tabular}{|l|c|c|}
\hline \multicolumn{1}{|c|}{ Category } & Frequency & Percentage \\
\hline Diploma & 1 & 16.7 \\
\hline Bachelors degree & 4 & 66.7 \\
\hline Masters degree & 1 & 16.7 \\
\hline Total & 6 & 100 \\
\hline
\end{tabular}

Source: Author's calculations2012

The data in the table 4.4 above shows that the majority $(66.7 \%)$ of the respondents had a bachelor's degree. A bar graph illustrating the data is shown below;

Figure 4.3 Academic Qualification of the Dean of Studies

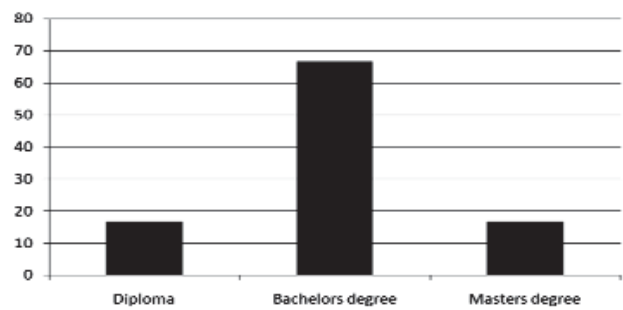

\subsection{Years of service}

The study sought to establish the years the dean of studies and the principals had served. The data in the table 4.5 below was elicited.

Table 4.5: Dean of Studies' Years of Service

\begin{tabular}{|l|c|c|c|c|}
\hline \multirow{2}{*}{ Year Interval } & \multicolumn{2}{|c|}{ Principals } & \multicolumn{2}{c|}{ Dean of studies } \\
\cline { 2 - 5 } & $\mathrm{F}$ & $\%$ & $\mathrm{~F}$ & $\%$ \\
\hline Less than 1 year & 0 & 0 & 0 & 0 \\
\hline 1-5 years & 0 & 0 & 0 & 0 \\
\hline 6-10 years & 1 & 16.7 & 2 & 33.3 \\
\hline 11-15 years & 2 & 33.3 & 3 & 50 \\
\hline Above 15 years & 3 & 50 & 1 & 16.7 \\
\hline \multicolumn{1}{|c|}{ Total } & 6 & 100 & 6 & 100 \\
\hline
\end{tabular}

Source: Author's calculations 2012

The data in the table above shows that the majority (50\%) of the principals had served as head teachers for over 15 years while the majority (50\%) of the dean of studies had served as teachers for 11-15 years. These findings therefore, not only reflect the effect of teachers' experience but also may reflect the effect of teacher efficiency on academic achievement. Students' performance is to some extent influenced by teachers experience with the subject matter. The findings are illustrated in the bar graph below; 
Figure 4.4. Dean of Studies Years' of Service

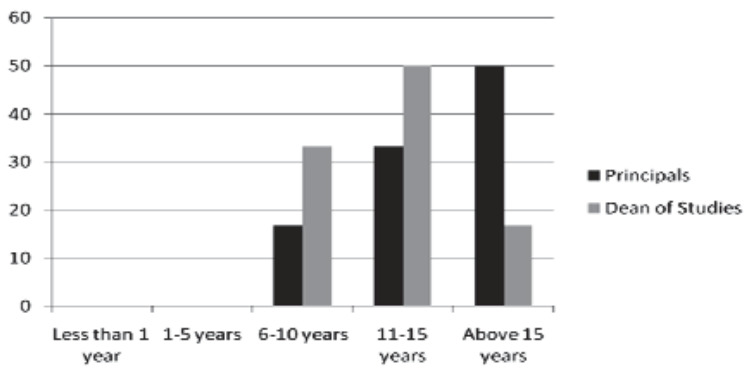

\subsection{Responsibility held by the students in the school}

The study sought to establish the responsibility held in the school by the sampled students. The findings are shown in the table 4.6 below;

Table 4.6: School Responsibility held by Students

\begin{tabular}{|l|c|c|}
\hline \multicolumn{1}{|c|}{ Responsibility } & Frequency & Percentage \\
\hline None & 92 & 76.7 \\
\hline Prefect & 20 & 16.6 \\
\hline Captain & 2 & 1.7 \\
\hline Games Captain & 6 & 5 \\
\hline Total & 120 & 100 \\
\hline
\end{tabular}

Source: Author's calculations 2012

The data above shows that the majority (76.7\%) of the students who participated in this study were not given any leadership responsibility in the school. $16.6 \%$ of the students were prefects, $5 \%$ were games captains and only $1.6 \%$ of them were a school captain. the information is further illustrated by the bar graph below;

Figure 4.5. School Responsibility held by Students

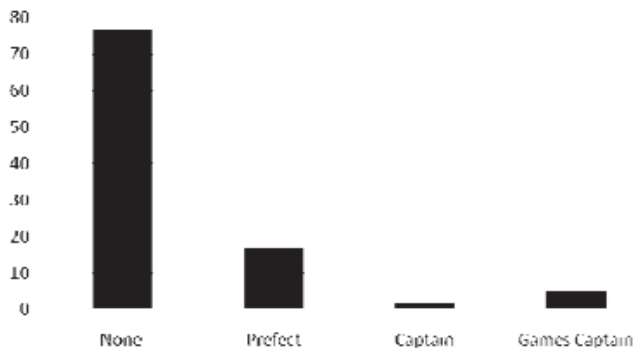

\subsection{Causes of students' Indiscipline in Secondary Schools}

The first study objective sought to identify the causes of indiscipline in public day secondary schools in Ruiru District. According to Okumbe (1985) indiscipline has causes that exist in the school, in the society and in the psychological states of the students. To collect data on the causes of indiscipline in secondary schools the questionnaire had items that sought to identify the various causes of students' indiscipline. The teachers and students were required to provide pertinent information regarding the variables of discipline. The data obtained from the questionnaires is shown in the table 4.7 below 
Table 4.7: Causes of students' Indiscipline in Secondary Schools.

\begin{tabular}{|l|c|c|c|c|c|}
\hline \multicolumn{1}{|c|}{ Causes of student indiscipline } & SA & A & U & D & SD \\
\hline 1. Harsh school rules and regulations & 20 & 13.3 & 4 & 17.3 & 45.3 \\
\hline 2. Frequent transfer of effective teachers & 16 & 17.3 & 4 & 22.7 & 40 \\
\hline 3. Inadequate and poor quality of food & 37.3 & 13.3 & 9.3 & 8 & 32 \\
\hline 4. Excessive CATs administered to students & 10.7 & 8 & 6.7 & 26.7 & 48 \\
\hline 5. Admission of students from other schools & 13.3 & 26.7 & 10.7 & 8 & 41.3 \\
\hline 6. Students' entry marks in form one admissions & 16 & 20 & 13.3 & 18.7 & 32 \\
\hline 7. Lack of disciplinary measures & 29.3 & 16 & 6.7 & 13.3 & 34.7 \\
\hline 8. Breakdown of cultural and moral values in the society & 21.3 & 25.3 & 12 & 18.7 & 22 \\
\hline 9. Poor performance in KCSE & 14.7 & 16 & 9.3 & 21.3 & 38.7 \\
\hline 10. Students resentment towards the school & 17.3 & 18.7 & 16 & 20 & 28 \\
\hline 11. Poor hygiene and safety standards & 24 & 16 & 8 & 22.7 & 29.3 \\
\hline 12. The banning of the corporal punishment/caning & 41.3 & 17.3 & 8 & 6.7 & 26.7 \\
\hline 13. Peer pressure & 54.7 & 26.7 & 4 & 2.7 & 10.7 \\
\hline 14. Overcrowding in the classrooms & 16 & 13.3 & 6.7 & 26.7 & 37.3 \\
\hline 15. Lack of clearly defined measures against indiscipline & 17.3 & 28 & 14.7 & 20 & 20 \\
\hline 16. Drug abuse & 38.7 & 21.3 & 9.3 & 8 & 21.3 \\
\hline 17. Poor teacher-pupil relationship & 36 & 22.7 & 10.7 & 17.3 & 13.3 \\
\hline 18. Shortage of teachers and learning materials & 30.7 & 18.7 & 5.3 & 17.3 & 28 \\
\hline 19. Lack of support services like guidance and counseling & 38.7 & 26.7 & 2.7 & 9.3 & 22.7 \\
\hline 20. Lack of role models in the school & 25.3 & 28 & 5.3 & 25.3 & 16 \\
\hline 21. Ignoring of students complaints & 60 & 16 & 2.7 & 5.3 & 16 \\
\hline 22. Unresponsive administration & 30.7 & 16 & 18.7 & 14.7 & 20 \\
\hline
\end{tabular}

$\mathrm{SA}=$ Strongly Agee, $\mathrm{A}=$ Agree, $\mathrm{U}=$ Undecided, $\mathrm{D}=$ Disagree, $\mathrm{SD}=$ Strongly Disagree

Source: Author's calculations 2012

Regarding the harsh school rules and regulations, majority (45.3\%) strongly disagreed that it was a cause of indiscipline while $20 \%$ strongly agreed. This agrees with the statement by Chaplain (2003) who observed that the goal pursued with rules for the classroom and the whole school leads to a safe environment and good working relationship. Rules should be clear, achievable and be subject to the school policy and government regulations. The study further revealed that majority $40 \%$ strongly disagreed that frequent transfer of effective teachers was a cause of indiscipline as opposed to the $16 \%$ who agreed.

Concerning the poor food quality being a cause of indiscipline, the majority $37.3 \%$ strongly agreed that it was a cause of indiscipline as opposed to the $8 \%$ who disagreed. The study further revealed that the majority (48\%) respondents strongly disagreed that those excessive CATs being administered to the students were a cause of unrest as opposed to $10.7 \%$ who strongly agreed.

The study established that majority (41.3\%) strongly disagreed that admission of students from other schools was a cause of indiscipline while $26.7 \%$ agreed. Majority (32\%) also strongly disagreed that admission marks for form one had any impact on student discipline as opposed to $20 \%$ who agreed.

In regards to lack of disciplinary measures, majority (34.7\%) disagreed that it was a cause of indiscipline in students while $29.3 \%$ strongly agreed that it was a contributing factor. On the issue of breakdown of cultural and moral values in the society, majority $25.3 \%$ agreed that it was a cause of indiscipline in schools while $18.7 \%$ disagreed. This agrees with Stangham (1989) who noted that the modern society is becoming more indisciplined, with enhanced lawlessness, violence and permissiveness. Furthermore, Mutie (1999) asserts that indiscipline is a cancer in many schools and can be attributed to negative internal and external influences, which cause students to lack a sense of direction and a sense of purpose. What we have given teenagers is immorality, pornography, violence and more violence. They will replicate what we have given them.

The study established that majority (38.7\%) strongly disagreed that poor performance in KCSE was a cause of student's indiscipline as opposed to the $16 \%$ who agreed. The study further established that the majority (28\%) of the respondents disagreed that Students resentment towards the school was a cause of indiscipline while $18 \%$ were of that view. 
The study established that majority (29.3\%) strongly disagreed that poor hygiene and safety standards in the schools, was a cause of student indiscipline while $24 \%$ agreed. The study further established that the majority (41.3\%) strongly agreed that banning of the corporal punishment/caning was a cause of students' indiscipline in secondary schools as opposed to $26.7 \%$ who disagreed.

In regard to peer pressure, majority (54.7\%) strongly agreed that it was a cause of student indiscipline as opposed to $10 \%$ who disagreed. This is in agreement to Cowley (2001) who argued that peer pressure among learners is a strong factor in the disruptive behaviour of learners. In the classroom the learner who can manage to make the whole class laugh at the teacher gains a great deal of status within the group. The study further established that the majority (37.3\%) strongly disagreed that overcrowding in the classrooms was a cause of students' indiscipline as opposed to the $16 \%$ who agreed.

Majority (28\%) agreed that lack of clearly defined measures against indiscipline was a cause of indiscipline in secondary schools, while $20 \%$ disagreed.

The study established that 38\% strongly agreed that drug abuse was a cause of indiscipline in schools while $21.3 \%$ strongly disagreed. This is in line with Jones and Jones (1995) who state that social factors in the life of a child may positively or negatively influence his/her behaviour. They mention family break-ups, poverty, stressful lives and substance abuse.

The study further established that the majority (36\%) strongly agreed that poor student-teacher relationship was a cause of student indiscipline while $13.3 \%$ strongly disagreed. Majority (30.7\%) strongly agreed that shortage of teachers and learning materials was a cause of students' indiscipline while $17.3 \%$ disagreed to that issue. The teacher shortage leads to large number of pupils in a class and hence low discipline levels. Alexander and Carla (1995) recommend that schools that are smaller and whose curriculum is easy to adjust may contain programmes aimed at changing perpetrators or aimed at prevention of ill-discipline.

In regard to support services like guidance and counseling, majority (38.7\%) strongly agreed that Lack of support services like guidance and counseling was a cause of students' indiscipline as opposed to $22.7 \%$ who disagreed to the issue. The study further established that majority (28\%) agreed that Lack of role models in the school was a cause of students' indiscipline as opposed to the $16 \%$ who disagreed. These findings supports Okumbe (1985) that the students are exposed to models in the society. They read thrilling stories, watch violence on television and even in real life situations. There are so many indiscipline acts that students are imitating and therefore they have learnt from the society around them.

Concerning ignoring of students' complaints, majority (60\%) strongly agreed that it was a cause of indiscipline as opposed to the $16 \%$ who disagreed. This is supported by the findings of Rwamba (2000) that lack of democratic leadership together with communication breakdown is a major cause of indiscipline in schools. The study further established that majority (30.7\%) strongly agreed that unresponsive administration was a cause of students' indiscipline in secondary schools.

From the findings, the factors highlighted as the major causes of indiscipline in schools were: poor food quality, lack of disciplinary measures, banning of corporal punishment, peer pressure, poor teacher-student relationship, shortage of teachers, ineffective guidance and counseling, lack of role models, ignoring students complains and unresponsive school administration.

\subsection{Relationship between Students' Discipline and their Academic Performance}

The second study objective sought to establish the relationship between students discipline and their academic performance. According to Ovell and Suaning (2001), discipline in schools is essential for effective learning, good teacher relationship and peer adjustment. A democratic form of discipline leads to a healthy classroom environment that in turn promotes respect for education and a desire for knowledge. The students and teachers were asked to give their views on the relationship between discipline and academic performance. The data elicited is shown in the table 4.8 below;

Table 4.8: Relationship between Students' Discipline and their Academic Performance

\begin{tabular}{|l|c|c|c|c|c|}
\hline Statement & SA & A & U & D & SD \\
\hline Discipline in schools is essential for good learning & 80 & 16 & 2.7 & 0 & 1.3 \\
\hline Discipline is essential for good teacher relationship & 64 & 29.3 & 1.3 & 2.7 & 2.7 \\
\hline
\end{tabular}




\begin{tabular}{|l|c|c|c|c|c|}
\hline Student indiscipline affects their academic performance & 33.3 & 51.3 & 2.7 & 8 & 4.7 \\
\hline Indisciplined students in your school perform well in exams & 1.3 & 6.7 & 8 & 13.3 & 70.7 \\
\hline Indisciplined students study well in classes & 4 & 4 & 2.7 & 26.7 & 62.7 \\
\hline Indisciplined students bring a conducive learning environment in schools & 4 & 2.7 & 5.3 & 16 & 72 \\
\hline Indisciplined students relate well with teachers & 4 & 1.3 & 2.7 & 18.7 & 73.3 \\
\hline Indisciplined students have ample reading time & 8 & 4 & 14.7 & 21.3 & 52 \\
\hline Teachers are blamed for indiscipline in schools. & 21.3 & 29.3 & 12 & 17.3 & 20 \\
\hline Violence affects students learning & 50.7 & 17.3 & 8 & 12 & 10.7 \\
\hline Unrests cause time wastage & 32 & 21.3 & 16 & 10.7 & 20 \\
\hline Indisciplined students lead a good life after schooling & 4 & 0 & 5.3 & 10.7 & 80 \\
\hline
\end{tabular}

$\mathrm{SA}=$ Strongly Agree, $\mathrm{A}=$ Agree, $\mathrm{U}=$ =Undecided, $\mathrm{D}=$ Disagree, $\mathrm{SD}=$ Strongly Disagree

\section{Source: Author,s calculations 2012}

The results on the table above indicate definite trends regarding the respondents' impression of the role of discipline on the students' academic performance. The study established that discipline is essential for good learning in schools and hence good academic performance. This is elicited by the majority (80\%) who strongly agreed, while only $1.3 \%$ disagreed. This agrees with Wayson and Pinnell (1994) that good discipline helps to develop desirable student behavior. If a school has effective discipline, the academic performance will be good. With regards to discipline being essential for good student teacher relationship, majority (64\%) strongly agreed that discipline is essential for good student-teacher relationship which in turn leads to good academic results while the minority $2.7 \%$ disagreed. This is because indiscipline pushes a wedge between the teacher and the student and this goes along with the findings of Akala (2002) that students and teachers in schools affected by unrest find it difficult to restore working relationship after the unrest.

The study further established that the majority $51 \%$ agreed that student indiscipline affects their academic performance while only $8 \%$ disagreed. Majority (70.7\%) strongly disagreed that the indisciplined students in school perform well in exams while only $4 \%$ agreed and this agrees with Gawe, Vakalisa and Jacobs (2001) who stated that if a school lacks effective discipline, the achievement academically will be poor. This implies that the indisciplined students end up performing poorly academically. The study further established that majority (62.7\%) strongly disagreed that indisciplined students study well in classes.

In regards to the issue of indisciplined students and conducive learning environment in schools, majority $72 \%$ strongly agreed that the indisciplined students brought un conducive learning environment in the schools. This agrees with the statement by Ovell and Suaning (2001) who noted that discipline in schools is essential for effective learning, good teacher relationship and peer adjustment. This then leads to poor grades in the examinations. The study further established that the indisciplined students do not relate well with the teachers as indicated by the majority (73.3\%). This is in line with Griffin (1994) that most people equate falling academic standards in schools to low standards of students' discipline.

The study further established that the indisciplined students did not have enough reading time as indicated by the majority (52.7\%). The little reading time the indisciplined students have negatively affects their academic performance. The study established that teachers get blamed for the students' indiscipline as indicated by the majority (29.3\%) who agreed to the statement. These findings are in agreement with Vockell (1991), who argue that in United Arab Emirates, teaching methods were blamed for the children's indiscipline.

The study established that the indisciplined students do not lead a good life even after completing the school. This was indicated by the majority (80\%). In regards to the issue of violence in students, the study established that violence affects the students learning, as indicated by the majority (50.7\%). As Mumo (2004) in her research study on student unrests and indiscipline reported that discipline is considered vital for students' academic and social success. A good academic qualification without a good foundation of discipline of the individuals is of no use to the individuals, their families and the society. The study further established that students Unrests causes time wastage as indicated by the majority (32\%). Time wastage largely affects students, academic performance.

From the data on table 10 above, it is clear that; discipline in schools is essential for good learning and good teacher-student relationship, that student indiscipline affects their academic performance ,the indisciplined students do not perform well in examinations, violence affects students learning, unrests causes time wastage and that indisciplined students lead a bad life after schooling. Indiscipline was also found to destroy the school's study environment and also affects the whole school cohesion. 


\subsection{Challenges Facing Teachers in Dealing with Students' Indiscipline}

The study sought to establish the challenges facing teachers and the principals in dealing with students' indiscipline. Charlton and David (1993) assert that if there is no proper family environment, presence of social differences and learners are from disadvantaged social areas, this could lead to bad discipline and negative results academically. Teachers and the students were asked to give their views on the challenges facing teachers in dealing with indiscipline cases. The findings are revealed in the table 4.9 below ;

Table 4.9: Challenges facing teachers in dealing with students' indiscipline.

\begin{tabular}{|l|c|c|c|c|c|}
\hline \multicolumn{1}{|c|}{ Challenges } & SA & A & U & D & SD \\
\hline 1. Inadequate support from parents and other stakeholders & 40 & 28 & 9.3 & 8 & 14.7 \\
\hline 2. Lack of well structured guidance and counseling programme. & 25.3 & 37.3 & 2.7 & 20 & 14.7 \\
\hline 3. Withdrawal of corporal punishment & 30.3 & 20.3 & 14.7 & 16 & 18.7 \\
\hline 4. Large number of students in a classroom & 16 & 41.3 & 2.7 & 26.7 & 13.3 \\
\hline 5. Preoccupation with mean scores & 16 & 38.7 & 18.7 & 12 & 14.7 \\
\hline 6. Fear of being taken to court & 41.3 & 18.7 & 9.3 & 14.7 & 14.7 \\
\hline 7. Fear of interdiction & 8 & 31.3 & 34.7 & 14.7 & 11.3 \\
\hline 8. Drugs and substance abuse by students & 41.3 & 22.0 & 5.3 & 16 & 16 \\
\hline
\end{tabular}

$\mathrm{SA}=$ Strongly Agree, A=Agree, U=Undecided, D=Disagree, SD=Strongly Disagree

\section{Source:Author's calculations 2012}

Inadequate support from parents and other stakeholders was highlighted as one of the challenges as elicited by the majority (40\%) who strongly agreed, while $14.7 \%$ strongly disagreed. This implies that the parents and other educational stakeholders did not fully support the teachers and the school administration at large in instilling discipline to the students.

In regard to guidance and counseling, the majority (37.3\%) agreed that Lack of well structured guidance and counseling programmes was a great challenge in management of students discipline while $14.7 \%$ disagreed. This implies that the majority of the schools did not have well structured guidance and counseling programmes and that it was a challenge in dealing with indiscipline cases. Eggleton (2001) says that effective instruction, accompanied by wide effective classroom management strategies and alternative school programmes that aim to discipline for reform, should form the disciplinary approach in schools. Disciplinary strategies for reform may include guidance and counseling and remedial assistance.

The study further established that majority (30\%) strongly agreed that withdrawal of corporal punishment was a challenge to instilling discipline to the students, while (18.7\%) disagreed. This was so because it limited the teachers' options of dealing with the indiscipline cases. Evertson, Emmer and Warsham (2003) suggest as an alternative to corporal punishment educators should help each learner to realize that his/her behaviour is not acceptable and can be transformed. They suggest teachers should not attribute all the bad behaviour to the child's choice.

The study established that majority $41.3 \%$ agreed that large number of students in a classroom was also a challenge in dealing with the indiscipline cases in the schools while $13.3 \%$ disagreed. The big numbers of learners that teachers have to deal with in one classroom are a daunting and intimidating prospect (Fontana, 1985). People who take interest in the education of children are aware of this problem. Teachers agree that once the class size rises above 35 , it is impossible to maintain discipline, or even an acceptable low noise in the classroom.

The study established that majority (38.7\%) agreed that the schools were preoccupied with improving the mean scores and that little attention was being paid to the discipline. Jones (1994) says schools have not adapted to students non academic needs. Teachers tend to be examination oriented hence the curriculum does not cater for the holistic development of the student. High expectation in performance of national examinations causes teachers to be preoccupied with testing at the expense of character development.

The study further established that majority (41.3\%) agreed that Fear of being taken to court was a challenge to the teachers in their duty of instilling discipline, while 14\% disagreed. This is in agreement with Kanja (2008) who note that, teachers have taken a back seat in discipline as there have been cases of teachers being dragged to court for punishing students which have prompted many to take a back seat over students behavior.

With regards to fear of interdiction, majority (31.3\%) agreed that it was a challenge to the effective discipline in the 
schools, while $11.3 \%$ disagreed. The study further established that the majority (40.3\%) strongly agreed that drugs and substance abuse by students was a challenge to the management of discipline while $16 \%$ of the respondents disagreed that it was a problem.

The findings reveal that among the challenges facing teachers in dealing with students' indiscipline were; inadequate support from parents and other stakeholders, ineffective guidance and counseling, withdrawal of corporal punishment, large number of students in a classroom, and that most schools are preoccupied with improving the mean scores. The teachers also indicated that they feared of being taken to court and interdiction by their employer.

\subsection{Possible Strategies for Improving Discipline}

The study sought to establish what the respondents think could be the practical solutions to the identified indiscipline in schools problem. The findings are presented in the table 4.10 below;

Table 4.10: Possible Strategies for improving discipline

\begin{tabular}{|l|c|c|c|c|}
\hline \multicolumn{1}{|c|}{ Strategies that can be used to curb indiscipline } & \multicolumn{2}{c|}{ Agreed } & \multicolumn{2}{c|}{ Disagreed } \\
\cline { 2 - 5 } & $\mathrm{F}$ & $\%$ & $\mathrm{~F}$ & $\%$ \\
\hline 1. Detention, isolation, time out (short duration). & 76 & 60 & 50 & 40 \\
\hline 2. Suspension (from 1 day to 2 weeks). & 71 & 56 & 55 & 44 \\
\hline 3. Manual Work (light to hard work). & 78 & 62 & 48 & 38 \\
\hline 4. Codes of conduct / rules - enforcing. & 88 & 70 & 38 & 30 \\
\hline 5. Parent involvement. & 111 & 88 & 15 & 12 \\
\hline 6. Privilege withdrawal. & 87 & 69 & 39 & 31 \\
\hline 7. Professional support - psychologists, counselors etc. & 106 & 84 & 14 & 16 \\
\hline 8. Small class sizes. & 57 & 45 & 69 & 55 \\
\hline 9. Effective instruction (good lessons; well prepared lessons). & 110 & 87 & 16 & 13 \\
\hline 10. Reinforcement of good behaviour by praise and ignoring unwanted behaviour. & 79 & 63 & 47 & 37 \\
\hline 11. Good behaviour management programmes. & 112 & 89 & 14 & 11 \\
\hline 12. Verbal and non-verbal interventions. & 87 & 69 & 39 & 31 \\
\hline 13. The use of humour. & 82 & 65 & 44 & 35 \\
\hline 14. Reprimanding only. & 82 & 65 & 44 & 35 \\
\hline 15. Teaching regularly and attending all lessons. & 100 & 79 & 26 & 21 \\
\hline
\end{tabular}

Source:Author's calculations 2012

Among the strategies suggested to help deal with students indiscipline cases were; Detention, isolation, time out (short duration) as agreed by the majority (60\%) noted by Dadisman et al (1990) that after-school detention and revocation of privileges like recess approaches are more enlightened and constructive than beating. Suspension (from 1 day to 2 weeks) as agreed by (56\%) and manual work (light to hard work) as agreed by (62\%).

Majority (88\%) agreed that the parental involvement was a solution to the student indiscipline problem while (70\%) agreed to enforce code of conduct and school rules and regulations in line with Chaplain (2003) that goal pursued with rules for classroom and the whole school leads to a safe environment and good working relationship. (69\%) suggested that privileges be withdrawn from the misbehaving students in order to shape their behaviors.

Majority (84\%) suggested that professional support - psychologists, counselors etc. be availed to the students with discipline problems as suggested by Evertson, Emmer and Warsham (2003) that educators should help each learner to realize that his/her behaviour is not acceptable and can be transformed. However majority (60\%) disagreed that small class sizes would help in maintaining discipline in the schools.

Another strategy suggested by the majority (87\%) was effective instruction (good lessons; well prepared lessons) in line with Eggleton (2001) that effective instruction accompanied by wide effective classroom management strategies and alternative school programmes should form the disciplinary approach in schools. (66\%) suggested that reinforcement of good behaviour by praise and ignoring unwanted behavior would help to curb the indiscipline menace.

Good behaviour management programmes were also suggested by the majority (89\%) while (69\%) were of the view that Verbal and non-verbal interventions would help in shaping the behavior of the students as noted in agreement with Weinstein and Mignano (1993). (65\%) agreed to the use of humour in line with Weinstein and Mignano (1993) that 
humour can be used to defuse tension in classroom and can gently remind students to mend their ways. $65 \%$ agreed to reprimand the undisciplined students as a means of enhancing good behavior as argued by Docking (1996) that reprimanding quickly spells out how far an unacceptable behaviour can be tolerated. $79 \%$ agreed that teaching regularly and attending all lessons would keep all the students busy and help in management of discipline.

Other strategies suggested by the principals include, reinstating of the corporal punishment by the government so as to deal with the minor indiscipline issues since it is less time consuming and hence more effective than these other methods.

\section{Conclusion}

It can be concluded that the students discipline is affected by many factors that include: the school type variables such as lack of support services and guidance and counseling, poor food quality, lack of enough learning materials, poor teacherstudent relationship, ignoring students complains, and unresponsive administration. The societal variables also affected the students discipline and they include: peer pressure drug abuse and lack of role models.

It can also be concluded that indiscipline in schools negatively affects learning, leads to time wastage for both the Indisciplined and disciplined students, affects the teacher-student relationship, and disrupts learning environment and the overall effectiveness of the school and the education system. Indiscipline was also found to lead to poor academic results in schools, to the students causing it and the resultant ripple effect affects the innocent students learning and the overall academic performance.

Finally discipline is a vital ingredient for the success of students' academic performance, both in and after school. However, the major challenge to indiscipline problems lies in the hands of the school management, the students and the parents. The vice of indiscipline extends its effects to even the innocent and disciplined students in the schools and affects the overall academic performance. It is important to implement the necessary guidelines and policies that can effectively handle most of indiscipline cases, dealing with the original causes of the actions.

\section{References}

Akala, W. J. (July 17, 2002). A long history of pupils' discontent and strikes. Daily nation http://www.nationaudio.com/News/DailyNation 117072000/Features/Features4.

Alexander, Jr. R. \& Carla, M.C. (1995). A critical review of strategies to reduce school violence. Social Work in Education, 17(2), pp: 1-6. Algozzine, B. \& Kay, P. (2002). Preventing problem behaviour: A handbook of successful prevention strategies. Thousand Oaks: Corwin Press.

Borg, W. R. \& Gall, M. D. (1989). Educational Research: An Introduction .New York: Longman Inc

Chaplain, R. (2003). Teaching Without Disruption in the Primary School: A model for Managing Pupil Behaviour. London: Routledge Falmer.

Charles, C.M. \& Charles, M. G. (2004). Classroom Management for Middle-grade Teachers. New York: Allyn and Bacon.

Charles, C.M. (1996). Building classroom discipline.(5th ed). United States of America: Longman publishers.

Charlton, T. \& David, K. (1993). Managing Misbehaviour in Schools_(2 ${ }^{\text {nd }}$ ed.). London: Routledge.

Cowley, S. (2001). Getting the buggers to behave: Why do students misbehave? What can I do about it? And what should I not do about it? London: Continuum.

Creswell, J.W (2007).Qualitative Inquiry And Research Design Among Five Approaches.California: Sage publications Inc.

Dadisman, M; Manahan, G.H. \& Quade V. (1990). Corporal punishment "whipping" up trouble in schools. Human rights: Journal of the Section of Individual Rights and Responsibilities, 17 (3), 8 - 9.

Docking, J. (1996). Managing behaviour in the primary school. (2nded.). London: David Fulton Publishers.

Dunham CM, LaMonica C. (1994) Prolonged tracheal intubation in the trauma patient. Journal of Trauma -Injury Infection and Critical Care. 1994; 24:120-124.

Eggleton, T. (2001). Discipline in schools. U.S. Department of Education: Educational Resources Information Centre.

Emmer, E.T, Evertson C.M ,and Worsham, M. E. (2003). Classroom Management For Secondary Teachers (6 th $^{\text {t }}$ ed) Boston :Allyn \& Bacon

Feshback, N. D. (1983). Learning to Care: A positive approach to child training and discipline. Journal of Clinical Child Psychology, 12(3), $226-271$.

Fontana, D. (1985). Class control: Understanding and guiding classroom behaviour. London: The British Psychological Society.

Galloway, A. (1997). Sampling: A Workbook. Retrieved from http://www.tardis.ed.ac.uk/ kate/qmcweb/scont.htm

Gay, L. R. (1992). Educational Research: Competence for Analysis and Applications. $4^{\text {th }}$ Edition.New York:Macmillan Publishers

Griffin,G.(1994).School Mastery Straight Talk about Boarding School Management .Nairobi : Lectern publication.

Grinnell, R.M. (1993). Social Work Research and Evaluation.4thedition.Peacock Publishers.

Hill, F.W. (1994). Creating safe schools. United Kingdom: Corwin 
Jones, V. F. \& Jones, L. S (1995). Comprehensive classroom management: Creating positive learning environment for all students_(4th ed.) Boston: Allyn and Bacon.

Kanja, B. M. (2008, Monday 21st July). Crisis Talks as Riots Rock More Schools. Daily Nation Newspaper. Nation Center. Nairobi.

Kerlinger, F. (1986). Foundations of Behavioral Research (3rd Edition) New York: Holt Renchart and Winston

Kirton, G. (2000). The dynamics of managing diversity: A critical approach, Oxford: Butterworth Heinemann.

Kothari C. R.( 2005). Research Methodology : Methods And Techniques, 2nd edition, New Age International (P) Ltd., Publishers, India, ISBN: 978-81-224-1522-3

Levin, J. \& Nalon, J. F. (1991). Principles of classroom management: A hierarchical Approach. New Jersey: Prentice-Hall Inc.

Lewis, R. B., \& Doorlay, D. H. (2006). Teaching special students in general education classrooms (7th ed.). Upper Saddle River, NJ: Pearson/Prentice Hall

McGuiness, J. (1994). Teachers, pupils and behaviour: A managerial approach. London: Cassell.

Mercure, C. M. (1995). Alternatives to corporal punishment abound: Nine ways to discipline without getting physical. Curriculum Review, 34 (5), 1 - 2.

Ministry of Education (2008). Report on School Unrest, Machakos. Nairobi.

MOE. (2001). Report of the Task Force on Student Discipline and Unrest in Secondary Schools. Nairobi: Jomo Kenyatta Foundation.

Monk, D. (1990). Educational cost differentials and rural schools: A broadened view. Administrators Notebook. 30(4), 1-4

Mothata, W. \& Squelch, J. (1997). Eight keys to effective school management in South Africa. Halfway House: Southern Book Publishers.

Muchemi, J. (2001). Students Face Life in Prison over Strikes. The Daily Nation Newspaper. Nation Center. Nairobi. Friday May 21. P. 5. Col. 1-3.

Mugenda, O.M and Mugenda ,A.G (2003).Research Methods: Quantitative and Qualitative Approaches .Nairobi: Kenyan Lectern Publishers

Mumo, S. N. (2004). Department of Education Administration Management Planning and Curriculum Development. PAC/M/508. Secondary Schools

Okumbe, J. A. (1985). Human Resources Management perspective. Nairobi: Educational Development and Research Bureau.

Orodho A.J. (2009). Elements of Education and Social Science Research Methods.Nairobi :Kanezja Enterprises

Orodho, A.J. (2010). Techniques of Writing Proposals \& Reports In Education and SocialSciences .Maseno/Nairobi:Kanezja Hp Enterprises:

Ovell G, and G. J. Suaning, (2001). "Effect of prosthetic vision acuity by ... for artificial human vision," presented at Proceedings of the SPIE, 2001

Psacharopoulous, G. \& Woodhall, M. (1985). Education and Development. An Analysis of Investment Choices. New York: Oxford University Press.

Republic of Kenya, (2002). National Development plan: 2002-2008.Nairobi: Government Printers.

Robertson, J. (1999). Effective classroom control: Understanding teacher - pupil relationships. London: Hodder \& Straughton.

Roffey, S. \& O'Reirdan, T. (2003). Plans For Better Behaviour in Primary:Management and Intervention. London :David Fulton Publishers

Roger, B. (2000). A Whole School Approach:- Behavioural Management. London: Paul Chapman Publishing Ltd.

Rogers, A. (2000). Classroom behaviour: A Practical Guide to Effective Teaching Behaviour Management and Colleague Support. London: Paul Chapman Publishing.

Rwamba, J. M. (2000). Disciplinary Problems Faced By Teacher in Primary Schools. A study of selected primary schools in south Imenti of Meru central, unpublished: M.E.D Project

Sisungo, Z.M. (2002). Head Teachers and Teachers Perceptions on the Influence of Management Skills Practice on School Climate in Secondary Schools in Western Province of Kenya. Unpublished Ph.D. Thesis, Egerton University.

Smith, C. J. \& Laslett, R. (1995). Effective classroom management: A teacher's guide. (2 $\left.{ }^{\text {nd }} \mathrm{ed}.\right)$. London: Routledge.

Smith, M.A. \& Misra, A. (1992). A comprehensive management system for students in regular classrooms. The Elementary School Journal, 92(3), 1-2.

Sonn, C. C., Fisher, A. T, \& Bustello, S. (1998). Sense of community: A different look at migrant adaptation. Paper presented at the 6th National Australia-New Zealand/ Aotearoa Community Psychology conference held at Hamilton/Kirikiriroa, 2-5 ${ }^{\text {th }}$ July.

Vockell, E.L. (1991). Corporal punishment: The pros and cons. Clearing House. 64(4), 278-283.

Wachira, M. (2004, August 19). Chronology of protest and destruction in schools. Daily Nation (Nairobi).

Walker, H.M. Colvin, G. \& Ramsay, E. (1995). Antisocial behaviour in schools: Strategies and best practices. Pacific Grove: Brooke I Cole Publishing Company.

Wayson, W.W. \& Pinnell, G.S. (1994). Discipline in schools. The International Encyclopedia of Education, Volume 3. Exeter: Pergamon. Weinstein, C. S. \& Mignano, A. (1993). Elementary School Management: Lessons from research and practice. New York: McGraw.

Williams, P. (1982). A user's guide to the General Health Questionnaire. Windsor, UK: Nfer Nelson.

Wilson, R. S. (1974). Interest and discipline in education. London: Routledge \& Kegan

Wolfgang, C. H. (1999). Solving discipline problems, methods and models for today's teachers. Boston: Allyn and Bacon.

Wragg, E. (2001). Class management in the primary school. London: Routledge Falmer. 
